\title{
ERRATUM
}

\section{Toward a systematic approach to assessment and care planning in palliative care: A practical review of clinical tools-ERRATUM}

PETER HUDSON, R.N., PH.D., ANNA COLLINS, B.SCI., M.HEALTH.PSYCH, ADAM BOSTANCI, PH.D.,

LISA WILLENBERG, M.P.H., NIKOLA STEPHANOV, PH.D., AND JENNIFER PHILLIP, PH.D., F.A.CH.P.M.

doi:10.1017/S1478951515000565, Published by Cambridge University Press, 11 June 2015.

Because of production errors, we are correcting the academic degrees and spelling for some of the authors

PETER HUDSON, R.N., PH.D., ANNA COLLINS, B.SCI., M.HEALTH.PSYCH,

ADAM BOSTANCI, M.SC., M.PHIL., PH.D., LISA WILLENBERG, B.H.SC., B.H.SC.(HONS), M.P.H., NIKOLA STEPANOV, B.N., GRAD. DIP. VET., M.ED., PH.D. (MELB.), CURRENT DJUR., AND JENNIFER PHILIP, PH.D, F.A.CH.P.M, M.MED., GRAD. DIP. PALL. MED., M.B.B.S.

\section{REFERENCE}

Hudson, P., Collins, A., Bostanci, A., Willenberg, L. \& Stephanov, N. (2015). Toward a systematic approach to assessment and care planning in palliative care: A practical review of clinical tools. Palliative and Supportive Care, doi:10.1017/ S1478951515000565. 